\title{
Male Infertility and Endocrinopathies in Kano, Northwestern Nigeria
}

\author{
${ }^{1,2}$ M. A. Emokpae, ${ }^{2}$ P. O. Uadia, ${ }^{3}$ A. Omale-Itodo and ${ }^{1}$ T. N. Orok \\ ${ }^{1}$ Department of Chemical Pathology, Aminu Kano Teaching Hospital, Kano, ${ }^{2}$ Department of Biochemistry, \\ University of Benin, Benin City and ${ }^{3}$ Department of Obstetrics and Gynaecology, Aminu Kano Teaching \\ Hospital, Kano, Nigeria \\ Reprint requests to: M. A. Emokpae, Department of Chemical Pathology, Aminu Kano Teaching Hospital, \\ P. M. B. 3452, Kano, Nigeria.E-mail: biodunemokpae@yahoo.com
}

\begin{abstract}
Background/Objective: Endocrinologic disorders and infertility are common all over the world; the prevalence of infertility is high in sub-Saharan Africa. Several authors have suggested that the increased incidence of infertility in Africa is due to high prevalence of sexually transmitted diseases. To evaluate the contributions of endocrine abnormalities to infertility in the male in Kano, Northern Nigeria.

Methods: A total of five hundred males, aged between 28 and 56 years were evaluated over a period of 4 years (2001 - 2004). The hormones were analyzed using electrochemiluminescene immunoassay technique.

Results: Hormonal abnormalities were detected in $22 \%$ oligospermic, $40.7 \%$ severe oligospermic, and $42.7 \%$ azoospermic subjects.

Conclusion: Endocrine abnormalities are common in the infertile males. The reason for the observed endocrinopathies is not known, appropriate laboratory investigations are essential for effective patients management. Further study to ascertain the cause(s) of hormonal derangements is suggested.
\end{abstract}

Key words: Male, infertility, endocrine abnormalities

\begin{abstract}
Résumé
Introduction/Objectif: Troubles endocrinologiques et la stérilité sont ordinaires dans le monde entier, la fréquence de la stérilité est élevée dans l'Afrique sous Saharian. Plusieurs auteurs avaient suggéré que l'augmentation dans la fréquence de la stérilité en Afrique est provoquée par la fréquence élevée des maladies sexuellement transmissibles. Afin d'étudier la contribution des abnormalités endocrines à la stérilité chez le sexe masculin à Kano, Nigéria du Nord.

Méthode: Un total de cinq cents sujets du sexe masculin âgé entre 28 et 56 ans ont été étudiés au cours d'une période de 4 ans (2001-2004) les hormones ont été analysés à travers la technique d' électrochémiluminescene immunoassay.

Résultats: Abnormalités hormonales ont été notées chez 22\% oligospermiques, 40,7\% oligospermique grave, et $42,7 \%$ sujets azoospermiques.

Conclusion: Abnormalités endocrine est ordinaire dans la stérile du sexe masculin. La raison pour cette observation endocrinopathies n'est pas connue, des enquiêtes laboratoires adéquates sont enssentielles pour la prise en charge efficace des patients. Des études supplementaires afin de savoir les cause de dérangements hormonaux sont exigées.
\end{abstract}

Mots-clés: Du sexe masculin, stérilité, abnormalités endocrine

\section{Introduction}

Endocrinologic disorders and infertility are common all over the world affecting up to $14 \%$ of couples. ${ }^{1-2}$ The prevalence of infertility is high in sub-saharan Africa, ranging from $20-40 \% .^{3-4}$ Although the African socio-cultural setting has before now, focused on the female, fertility problems are obviously shared between both male and female sexes. Male infertility may account for up to $40 \%$ of infertile couples. ${ }^{4}$
The main determinant of male potential is the quantity and quality of spermatozoa ejaculated during coitus. The causes of male infertility could be pretesticular, testicular, and post-testicular. ${ }^{5}$ The pretesticular and to some extent the testicular causes are mainly endocrine disorders originating from the hypothalamic-pituitary-gonadal-axis which have adverse effects on spermatogenesis. Male fertility is critically dependent upon normal hormonal milieu. Evaluations of the sub-fertile man require a complete 
medical history, physical examinations and specific laboratory studies. ${ }^{6}$ Appropriate evaluation and treatment of the sub-fertile man are critical in delivering suitable care to the infertile couple. ${ }^{7}$ Several authors have suggested that the increased incidence of infertility in Africa is due to high prevalence of sexually transmitted diseases. ${ }^{6,} 8$ Literature is scarce on the endocrine abnormalities in the infertile male in northern Nigeria.

\section{Materials and Methods}

Five hundred men who were investigated for infertility at the Aminu Kano Teaching Hospital, Kano, north western Nigeria from January 2001 December 2004. The hospital records of these patients have been retrospectively reviewed. The ages of the patients ranged from 28-56years with a mean of $36.2 \pm 3$.2years. Twenty normospermic males aged 2848years with a mean age of $39.5 \pm 2$.6years were used as control subjects. Ethical clearance was obtained from the Aminu Kano Teaching Hospital Ethics committee and the medical records of the subjects were retrieved from the medical records department.

Information regarding the past medical history, social history, physical examination of the testes, and results of semen analysis were extracted from medical records of individual patients. These subjects had no history of previous surgical operation. Only seventy two patients $(14.4 \%)$ admitted to consumption of alcohol occasionally while two hundred and ninety two (58.4\%) admitted smoking cigarettes. Records of hormonal assay were collated and analyzed. The assays done were testosterone, prolactin (PRL), follicle stimulating hormone (FSH) and luteinizing hormone (LH). The serum hormones were quantitated by Roche Elecsys 1010 (Germany), using electrochemiluminescene immunoassay technique.

\section{Results}

The results are shown in tables 1,2 and 3. A total of $209(41.8 \%)$ males were normospermic (sperm density $>20 \times 10^{6}$ cells $\left./ \mathrm{mL}\right), 145(29 \%)$ oligospermic (sperm density $2-19.9 \times 10^{6}$ cells $\left./ \mathrm{mL}\right\}, 59$ (11.8\%) severe oligospermic $\left(<2 \times 10^{6}\right.$ cells $\left./ \mathrm{mL}\right)$, and 87 $(17.4 \%$ ) azoospermic (no sperm at all). Of the 145 oligospermic males $32(22 \%)$ had hormonal abnormalities while $113(77.9 \%)$ had no hormonal abnormality. Twenty four of them had elevated FSH and LH with normal prolactin and low "normal" testosterone levels. While eight had diminished FSH levels and raised level of testosterone.

Twenty-four $(40.7 \%)$ of the severe oligospermic subjects had abnormal hormonal levels while thirty five $(59.3 \%)$ had no hormonal abnormality. Twentytwo had diminished levels of FSH, LH and testosterone while two subjects had elevated level of prolactin. Of the 87 azoospermic subjects, thirtyseven $(42.5 \%)$ had abnormal hormonal levels and fifty $(57.5 \%)$ had normal hormonal levels. Twenty (13.8\%) azoospermic subjects had elevated levels of FSH, LH and diminished testosterone level, with normal prolactin level. Fourteen $(16.1 \%)$ had diminished levels of FSH, LH and testosterone. Six $(6.9 \%)$ had elevated prolactin level while isolated elevated levels of LH and FSH were observed in three and two subjects respectively. Endocrine evaluations were not done on the 209 normospermic male subjects.

All the twenty control subjects with normal sperm cell count had their hormonal levels within normal reference ranges.

Table 1: Mean hormonal levels of oligospermic infertile males and normospermic subjects

\begin{tabular}{|c|c|c|c|c|c|c|c|}
\hline $\begin{array}{l}\text { Hormones } \\
\text { (reference } \\
\text { range) }\end{array}$ & $\begin{array}{l}\text { Control } \\
\left(>20 \times 10^{6}\right. \\
\text { cells } / \mathrm{ml}) \\
\mathrm{n}=20\end{array}$ & $\begin{array}{l}\text { Oligospermia } \\
\left(2-19.910^{6}\right. \\
\text { cells } / \mathrm{ml})\end{array}$ & & & $\begin{array}{l}\text { Severe } \\
\text { oligospermia } \\
\left(<2 \times 10^{6}\right. \\
\text { cells } / \mathrm{ml})\end{array}$ & & \\
\hline & & $\begin{array}{l}\text { Hormonal } \\
\text { abnormality } \\
\mathrm{n}=24\end{array}$ & $\mathrm{n}=8$ & $\begin{array}{l}\text { Normal } \\
\text { hormone } \\
\text { levels } \\
\mathrm{n}=113\end{array}$ & $\begin{array}{l}\text { Hormonal } \\
\text { abnormality } \\
\mathrm{n}=22\end{array}$ & $\mathrm{n}=2$ & $\begin{array}{l}\text { Normal } \\
\text { hormone } \\
\text { levels } \\
\mathrm{n}=35\end{array}$ \\
\hline $\begin{array}{l}\text { Prolactin } \\
(85-390 \\
\mathrm{miu} / \mathrm{ml})\end{array}$ & $\begin{array}{l}258.7 \\
\pm 1.19\end{array}$ & $\begin{array}{l}146 \\
\pm 1.82\end{array}$ & $\begin{array}{l}98.5 \\
\pm 0.91\end{array}$ & $\begin{array}{l}198.6 \\
\pm 3.41\end{array}$ & $\begin{array}{l}212.2 \\
\pm 11.1\end{array}$ & $\begin{array}{l}514.9 \\
\pm 7.21\end{array}$ & $\begin{array}{l}184.5 \\
\pm 2.41\end{array}$ \\
\hline $\begin{array}{l}\text { FSH } \\
(4.6- \\
12.4 \mathrm{miu} / \mathrm{ml})\end{array}$ & $\begin{array}{l}8.92 \\
\pm 0.03\end{array}$ & $\begin{array}{l}26.7 \\
\pm 0.38\end{array}$ & $\begin{array}{l}2.45 \\
\pm 0.09\end{array}$ & $\begin{array}{l}5.40 \\
\pm 0.09\end{array}$ & $\begin{array}{l}1.71 \\
\pm 0.28\end{array}$ & $\begin{array}{l}6.21 \\
\pm 0.12\end{array}$ & $\begin{array}{l}5.36 \\
\pm 0.06\end{array}$ \\
\hline $\begin{array}{l}\text { LH } \\
(4-8.6 \mathrm{miu} / \mathrm{ml}) \\
\text { Testosterone } \\
(2.8- \\
8.0 \mathrm{ng} / \mathrm{ml})\end{array}$ & $\begin{array}{l}6.51 \\
\pm 0.02 \\
6.26 \\
\pm 0.02\end{array}$ & $\begin{array}{l}12.86 \\
\pm 0.26 \\
3.02 \\
\pm 0.19\end{array}$ & $\begin{array}{l}5.84 \\
\pm 0.24 \\
9.64 \\
\pm 0.17\end{array}$ & $\begin{array}{l}8.01 \\
\pm 0.05 \\
5.41 \\
\pm 0.14\end{array}$ & $\begin{array}{l}1.90 \\
\pm 0.06 \\
1.54 \\
\pm 0.16\end{array}$ & $\begin{array}{l}5.26 \\
\pm 0.21 \\
7.32 \\
\pm 0.24\end{array}$ & $\begin{array}{l}7.26 \\
\pm 0.04 \\
5.28 \\
\pm 0.17\end{array}$ \\
\hline
\end{tabular}

FSH: follicle stimulating hormone; LH: luteinizing hormone 
Table 2: Mean hormonal levels in azoospermic infertile males

\begin{tabular}{|c|c|c|c|c|}
\hline Subjects & $\begin{array}{l}\text { Prolactin (reference } \\
\text { range } 86-390 \\
\mathrm{miu} / \mathrm{ml} \text { ) }\end{array}$ & $\begin{array}{l}\text { FSH (reference range } \\
4.6-12.4 \mathrm{miu} / \mathrm{ml} \text { ) }\end{array}$ & $\begin{array}{l}\text { LH (reference range } \\
4.0-8.6 \mathrm{miu} / \mathrm{ml})\end{array}$ & $\begin{array}{l}\text { Testosterone } \\
\text { (reference range } 2.8 \\
-8.0 \mathrm{ng} / \mathrm{ml} \text { ) }\end{array}$ \\
\hline Primary hypogonadism & 298.48 & 41.0 & 11.48 & 2.01 \\
\hline$(\mathrm{n}=12)$ & \pm 30.8 & \pm 4.26 & \pm 1.21 & \pm 0.41 \\
\hline Secondary & 214.6 & 2.88 & 2.40 & 2.81 \\
\hline $\begin{array}{l}\text { hypogonadism } \\
(\mathrm{n}=14)\end{array}$ & \pm 20.4 & \pm 0.21 & \pm 0.20 & \pm 1.08 \\
\hline Hyperprolactinaemia & 738.0 & 1.86 & 6.74 & 5.80 \\
\hline$(n=6)$ & \pm 48.7 & \pm 0.30 & \pm 0.69 & \pm 0.49 \\
\hline Isolated increase in $\mathrm{LH}$ & 313.5 & 7.11 & 11.31 & 7.67 \\
\hline $\begin{array}{l}\text { levels } \\
(\mathrm{n}=3)\end{array}$ & \pm 29.4 & \pm 2.07 & \pm 0.92 & \pm 0.60 \\
\hline Isolated increase in & 301.2 & 22.6 & 5.52 & 2.53 \\
\hline $\begin{array}{l}\text { FSH levels } \\
(\mathrm{n}=2)\end{array}$ & \pm 73.0 & \pm 1.51 & \pm 0.97 & \pm 0.32 \\
\hline Azoospermia with & 258.7 & 8.92 & 6.51 & 6.26 \\
\hline $\begin{array}{l}\text { normal hormone levels } \\
(\mathrm{n}=50)\end{array}$ & \pm 1.19 & \pm 0.03 & \pm 0.02 & \pm 0.02 \\
\hline
\end{tabular}

FSH: follicle stimulating hormone; LH: luteinizing hormone

Table 3: Mean hormonal levels in infertile males

\begin{tabular}{|c|c|c|c|c|}
\hline Subjects & $\begin{array}{l}\text { Prolactin (reference } \\
\text { range } 86-390 \\
\text { miu/ml) }\end{array}$ & $\begin{array}{l}\text { FSH (reference range } \\
4.6-12.4 \mathrm{miu} / \mathrm{ml} \text { ) }\end{array}$ & $\begin{array}{l}\text { LH (reference range } \\
4.0-8.6 \mathrm{miu} / \mathrm{ml})\end{array}$ & $\begin{array}{l}\text { Testosterone } \\
\text { (reference range } 2.8 \\
-8.0 \mathrm{ng} / \mathrm{ml} \text { ) }\end{array}$ \\
\hline Hypergonatropic & 222.24 & 33.9 & 12.18 & 2.50 \\
\hline $\begin{array}{l}\text { hypogonadism } \\
(\mathrm{n}=36)\end{array}$ & \pm 16.3 & \pm 2.31 & \pm 0.74 & \pm 0.3 \\
\hline Hypogonadotropic & 213.4 & 2.31 & 2.15 & 2.18 \\
\hline $\begin{array}{l}\text { Hypogonadism } \\
(\mathrm{n}=36)\end{array}$ & \pm 15.65 & \pm 0.26 & \pm 0.14 & \pm 0.61 \\
\hline Hypogonadotropic & 98.5 & 2.45 & 4.84 & 9.64 \\
\hline $\begin{array}{l}\text { Hypergonadism } \\
(\mathrm{n}=8)\end{array}$ & \pm 0.91 & \pm 0.09 & \pm 0.24 & \pm 0.17 \\
\hline $\begin{array}{l}\text { Hyperprolactinaemia } \\
(\mathrm{n}=8)\end{array}$ & $\begin{array}{l}626.5 \\
\pm 28.1\end{array}$ & $\begin{array}{l}4.03 \\
\pm 0.21\end{array}$ & $\begin{array}{l}6.01 \\
\pm 0.45\end{array}$ & $\begin{array}{l}6.56 \\
\pm 0.36\end{array}$ \\
\hline Isolated increase & 313.5 & 7.11 & 11.31 & 7.67 \\
\hline $\begin{array}{l}\text { in LH levels } \\
(\mathrm{n}=3)\end{array}$ & \pm 29.4 & \pm 2.07 & \pm 0.92 & \pm 0.60 \\
\hline $\begin{array}{l}\text { Isolated increase } \\
\text { in FSH levels } \\
(\mathrm{n}=2)\end{array}$ & $\begin{array}{l}301.2 \\
\pm 73.0\end{array}$ & $\begin{array}{l}22.6 \\
\pm 1.51\end{array}$ & $\begin{array}{l}5.52 \\
\pm 0.97\end{array}$ & $\begin{array}{l}2.53 \\
\pm 0.32\end{array}$ \\
\hline $\begin{array}{l}\text { Normal hormones } \\
\text { levels } \\
(\mathrm{n}=20)\end{array}$ & $\begin{array}{l}213 \\
\pm 2.40\end{array}$ & $\begin{array}{l}6.57 \\
\pm 0.06\end{array}$ & $\begin{array}{l}7.26 \\
\pm 0.04\end{array}$ & $\begin{array}{l}5.65 \\
\pm 0.12\end{array}$ \\
\hline
\end{tabular}

FSH: follicle stimulating hormone; LH: luteinizing hormone

\section{Discussion}

The result of this study has demonstrated that hypergonadotropic hypogonadism and hypogonadotropic - hypergonadism was present in oligospermic subjects, while hypogonatropic hypogonadism and hyperprolactinaemia was observed in severe oligospermic males. Similarly, primary hypogonadism, secondary hypogonadism and hyperprolactinaemia were observed in azoospermic males. These findings are similar to the report of other workers. ${ }^{9-10}$ However, this is different from the findings of khan et $\mathrm{al}^{11}$ who reported increased levels of FSH, LH and low testosterone level in all oligospermic and azoospermic subjects evaluated.
Most evidence in man and other mammalian species suggested that both LH and FSH through the action of testosterone are required for the initiation and maintenance of spermatogenesis. ${ }^{10-12}$ Testosterone is very important in maintaining the seminiferous epithelium. This action of testosterone is mediated through androgen receptors found within the sertoli cell. $^{13-14}$ Male hypogonadism may indicate an impaired production of testosterone by the Leydig cells or deficient spermatogenesis due to seminiferous tubular dysfunction because extensive biochemical communication occurs between the Leydig cells and the tubules. When there is disturbance in the hormones releasing processes the whole process leading to spermatogenesis is disrupted. Elevated 
serum FSH level may indicate a disturbance of seminiferous tubular function. Isolated elevation of FSH with normal LH was observed in two azoospermic subjects. It was earlier reported that such an elevation in FSH only without concomitant increase in LH might be due to pituitary tumor. ${ }^{16}$

Subhan et $\mathrm{al}^{17}$ reported that increase in FSH level in azoospermic males may reflect decreased testicular activity resulting in an alteration of the normal feed back mechanism between the testes and the hypothalamic pituitary axis, through an impairment of the sertoli cells and decreased in inhibin secretion.

Several authors have suggested reasons for the observation of secondary hypogonadism. The reasons advanced include chemical and physical agents such as heavy metals, toxic industrial fumes and prominent among the harmful physical agents is heat and radiation. $^{18-20}$ Environmental pollutants such as polychlorinated biphenyls (PCB) and PCB metabolites, which act as endocrine disrupting agents have been demostrated ${ }^{21-22}$

Hyperprolactinaemia was seen in two patients with severe oligospermia and six azoospermic subjects coupled with low semen volume (mean, $\left.1.2 \mathrm{~cm}^{3}\right)$. The mechanism by which Hyperprolactinaemia leads to infertility in women has been described by several authors ${ }^{4,23-24}$ but in man it is not well understood. However, increased prolactin reduces gonadotropin releasing hormone $(\mathrm{GnRH})$ secretion by slowing the frequency of GnRH pulses thereby reducing LH and FSH pulsatility. It also alters the positive feedback mechanism on the hypothalamus.

It is concluded that endocrinopathies are not uncommon in infertile African males. Appropriate laboratory investigations are therefore necessary for effective patients' management.

\section{References}

1. Infertility: A tabulation of available data on prevalence of primary and secondary infertility. WHO, Geneva, 1991;1- 15

2. Mosher WD, Pratt AF. Fecundity and infertility in the United Sates. 1965 - 1982. National Centre for Health Statistics (advance data) 1985; 104:1

3. Cates W, Farley TMM, Rowe PJ. Worldwide patterns of infertility: is Africa different? Lancet 1985; 14:595 - 598

4. Balsey MA. The epidemiology of infertility. A review with particular reference to sub-Saharan Africa. Bull WHO 1976; 54:321

5. Obafunwa JO, Elesha SO, Odunjo EO. Morphological changes found in the testes of 177 Nigerian males investigated for infertility. Afr J Med Sci 1993; 22:35 - 40
6. Okonofua F. Infertility and women's reproductive health in Africa. (Editorial) Afr J Reprod Health 1999: 1-2

7. Kolettis PW. Evaluation of the sub fertile man. Am Fam Physician 2003; 67):2165 - 2172

8. Emokpae MA. A review of laboratory investigations of male infertility. Niger $\mathrm{J}$ Med 1999;8:104-107

9. Nkposong EO. Management of infertility in males. Current Practice 1990;31-35

10. Steinberger E. Hormonal control of mammalian spermatogenesis. Physiol Rev 1971; 51:1 - 3

11. Steinberger E, Roof A, Gocher M, Smith RD. The role of androgens in the initiation of spermatogenesis in man. J Clin Endocrinol Metab 1973; 37:746 - 749

12. Burger HG, Baker HWG. Therapeutic considerations and results of gonadotropin treatment in male hypogonadotropic hypogonadism. Ann NY Acad Sci 1984; 438:447 $-450$

13. Grootegoen JA, Peters MJ, Mulder E, et al. Absence of nuclear androgen receptor in isolated germinal cells of rat testes. Mol Cell Endocrinol 1977; 9:159- 162

14. Meikle A, Stringham J, Wilson D, Dolman L. Plasma $\mathrm{S}$ and reduced androgens in men and hirsute women: role of adrenal and gonads. J Clin Endocrinol Metab 1979; 48:969

15. Colgen TJ, Bedard YC, Strawbride HTG, Duckspan MB, Klotz PG. Reappraisal of the value of testicular biopsy in the investigations of infertility. Fertil Steril 1980; 33:56 - 60

16. Emokpae MA, Uadia PO, Mohammed AZ, Omale-Itodo A. Hormonal abnormalities in azoospermic men in Kano, northern Nigeria. Indian J Med Res 2006;124:299-304

17. Dallinga JW, Moonen EJ, Dumoulin JC, Evers JL, Geraedts JP, Kleinjans JC. Decreased human semen quality and organochlorine compounds in blood. Hum Reprod 2002; 17: 1973 - 1979

18. Revich BA. Chemical substances in the Russian urban environment: hazard to human health and prospects for its prevention (abstract). Vestn Ross Akad Med Nauk 2002; 9:45 - 49

19. Kuku SF. African endocrine infertility: a review. Afr J Med Sci 1995; 24:111 - 123.

20. Thorner MO, Vance ML. Hyperprolactinaemia. In: Hiroo 1, Kazuo S, Sho Y (eds). Progress in endocrinology: proceedings of the $8^{\text {th }}$ International Congress of Endocrinology, Kyoto. $1988 ; 124-128$

21. Okonofua FE, Harris D, Odebiyi A, Kane T, Snow RC. The social meaning of infertility in south west Nigeria. Health Transition Review 1997; 7:205 - 220 